\title{
Examining the Relationship between Prospective Preschool Teachers' Self-Efficacy Beliefs in Science Education and Learning Styles
}

\author{
Oğuzhan Özdemir'1, Gamze Hastürk ${ }^{2 *}$ \\ ${ }^{1}$ Department of Science Education, Institute of Graduate Studies, Tokat Gaziosmanpaşa University, Tokat, Turkey, ${ }^{2}$ Department of Primary Education, \\ Dr., Tokat Gaziosmanpaşa University, Tokat, Turkey
}

*Corresponding Author: gamzeyalvac@gmail.com

\section{ABSTRACT}

This study was conducted to examine the relationship between the levels of prospective preschool teachers' self-efficacy beliefs in science education and learning styles. In this study, the correlational survey model was used. The sample of the research was composed of 193 (165 females and 28 males) prospective pre-school teachers studying in their $1^{\text {st }}, 2^{\text {nd }}, 3^{\text {rd }}$, and $4^{\text {th }}$ year in a faculty of education of a state university located in the Black Sea in Turkey. Data were collected using the "Science Education Self-Efficacy Belief Scale" developed by Enochs and Riggs (1990) and adapted into Turkish by Özkan et al. (2002) and "Kolb Learning Style Inventory" developed by Kolb (1984) and adapted into Turkish by Evin Gencel (2007) in the spring semester of the 2019-2020 academic years. Descriptive and inferential statistics were used in the statistical calculations of the data in the study. As a result of the study, it was determined that these prospective pre-school teachers' self-efficacy beliefs in science education were very high while their personal self-efficacy beliefs and result expectation sub-dimensions were at a high level. In addition, there is no statistically significant difference between prospective teachers' self-efficacy beliefs in science education, personal self-efficacy perception, and result expectation according to their learning styles. Based on the results obtained, to increase the success of prospective teachers in science and achieve desired goals in education, learning environments should be designed according to learning styles, and studies should be conducted to increase the quality of science education by making use of self-efficacy beliefs.

KEY WORDS: learning styles; preschool education; preschool science education; self-efficacy belief

\section{INTRODUCTION}

$\circlearrowleft$ in cience can be defined as the effort to regularly investigate and examine nature and natural events, to make a judgment as a result of these investigations and examinations, and to predict the events we may encounter in the rest of our lives with the judgments we reach. Science is part of our lives. Learning the phenomena of science that shape our world is very important for a more comfortable life. Çilenti (1985. p. 7) defines science as a process for examining the natural environment and a set of information based on organized information that is the product of this process. Science is an important issue for human life. It allows us to live our lives in a healthy, happy, and secure way. Thanks to science education, we are able to access more information such as our own bodies, the protection of the environment we live in, and the creation of a healthy living environment. Through science, we can investigate the air we breathe, the water we drink, healthy nutrition, the amount of food that needs to be consumed, and so on (Grieshaber and Diezmann, 2000; Yoshikawa et al., 2013).

Science education is a process beginning right from birth and continuing for the entire life span (Aktaş Arnas et al., 2007).
With an increase in both the mental and physiological development of each individual, the concepts they need to learn increases. Teaching these concepts is required to maintain a healthier and higher quality of life. The most important places where these concepts can be learned are educational institutions. Preschool education institutions are the first place where children meet science and nature (Gülay, 2010). In this period, children may unwittingly work like scientists. First, they start with exploring their environment and then perform many activities such as constantly asking questions, touching, comparing, and expressing an opinion due to their curiosity. It is necessary to pay attention to these features in the pre-school period (Erbaş et al., 2002). Pre-school education is very important in science and nature teaching. Children's interest in science can be increased and their misconceptions that may be encountered in the future can be prevented with the basic knowledge gained in the family and social environment. The experiences and acquisitions that children have in their preschool period not only affect their academic life but also shape their emotional and social life (Kesicioğlu, 2019).

The previous studies clearly reveal the importance of science education in pre-school period (see for example, Duschl et al., 2007; Eschach, 2011; Eshach and Fried, 2005). 
Thanks to science education it is possible to teach students how to solve problems, make conscious decisions, and how to think. Despite this emphasis, preschool teachers tend to teach science less than language and literacy, social studies, and the arts (Hanley et al., 2007; Hanley et al., 2009; Nayfeld et al., 2011). Therefore, students' scientific process skills such as hypothesizing, predicting, and interpreting are often underdeveloped in their early academic life (La Paro et al., 2004). To eliminate this problem, preschool teachers must have teacher competence.

Increasing science achievement is possible with science education given in the pre-school period when the foundations of science education are laid (Ayvac1 and Özbek, 2017; Kıldan and Pektaş, 2009; Nacar and Kutluca, 2020; Ünal and Akman, 2006). Preschool teachers should lay the foundations of science by motivating students to love science. For this reason, basic concepts related to science and nature should be given with pre-school science education. The effectiveness of science education in the pre-school period directly depends on teachers. The quality of teachers' training is directly related to their beliefs (Nespor, 1987). It is very important to examine the self-efficacy belief levels and learning styles of preschool teachers to teach science (Çamlıbel Çakmak, 2006). For this reason, it is important to determine the learning styles of prospective teachers. When the related literature is examined, there are studies on the levels of self-efficacy beliefs in science education and learning styles of prospective teachers from other branches (Özok Bulut, 2020; Can and Şahin Çakır, 2015; Çamlıbel Çakmak, 2016; Gözüm, 2015, Eğin Işık, 2019); however, there are no studies examining prospective pre-school teachers' self-efficacy beliefs in science education and learning styles together. Examining the relationship between prospective pre-school teachers' gender and class levels, science education self-efficacy belief levels, and learning styles is expected to contribute to the literature in organizing education programs, organizing learning environments, and achieving the desired level of science achievement.

Teachers' competence should not be evaluated only by their education and diplomas. The teacher should be competent in their field and have the necessary theoretical knowledge, besides that the teachers should also have feelings of faith and sincerity toward their profession (Jones and Carter, 2007). Prospective preschool teachers' knowledge, skills, and self-efficacy perceptions toward science education enable more effective classroom practices and science education. Teaching scientific processes at an early age has an impact on the student's self-efficacy beliefs in science in the coming years (Harlen, 1990 as cited in Hamurcu, 2003). There are inconsistencies in real science education in preschool classrooms. It can be said that these inconsistencies are mostly caused by the levels of teachers' self-efficacy beliefs in science education (Brown, 2005; Jones and Carter, 2007; Levitt, 2002; McDevitt et al., 1993). Self-efficacy is another factor that is necessary for achieving the desired success in science education. Bandura (1977) emphasizes that self-efficacy belief is dependent on the belief that a person can do that job or not. Bandura (1977) emphasizes that individuals should firstly trust themselves for performance and it is necessary to create a safe environment for individuals to express themselves.

Based on the stated characteristics, it can be thought that the learning styles of prospective pre-school teachers affect their levels of self-efficacy beliefs in science education. In this context, it is very important to investigate the relationship between the levels of prospective pre-school teachers' self-efficacy beliefs in science education and learning styles.

In this context, the purpose of this study was to examine the relationship between pre-school prospective teachers' selfefficacy belief levels and learning styles. For this purpose, the study sought answers to the following questions:

1. What is the level of prospective pre-school teachers' self-efficacy beliefs in science education (personal self-efficacy belief and result expectation)?

2. What are the learning styles of prospective pre-school teachers (Accommodator, Assimilator, Converger, or Diverger)

3. Do prospective pre-school teachers' self-efficacy beliefs in science education differentiate according to their learning styles?

4. Do prospective pre-school teachers' self-efficacy beliefs (personal self-efficacy beliefs, result expectations) differentiate significantly according to their gender and grade level?

5. Do prospective pre-school teachers' learning styles differentiate significantly according to their gender?

\section{METHODS}

\section{Research Design}

The research was carried out according to a descriptive survey model and correlational survey model. As such, it was aimed to determine participants' opinions or the characteristics of interests, skills, abilities, attitudes, etc., on a subject or event (Fraenkel and Wallen, 2006). In relational studies, the relationship between two or more variables is investigated (Karasar, 2006). In this study, the relational research method was used to describe the relationships between pre-school teachers' learning styles and self-efficacy belief levels in science education.

\section{Study Group}

The study was conducted with the first, second, third, and fourth years prospective teachers who consented to participate voluntarily in the Department of Preschool Education, Elementary Education Department of Education Faculty in a state university, in the fall semester between 2019 and 2020. The demographic characteristics of prospective teachers who participated in the study are given in Table 1 .

As seen in Table 1, 51 (26.4\%) of the prospective teachers in the sample group were in their $1^{\text {st }}$ year of study, $56(29.0 \%)$ were in their $2^{\text {nd }}, 53(27.5 \%)$ were in their $3^{\text {rd }}$, and $33(17 \%, 1)$ were 


\begin{tabular}{|c|c|c|c|c|c|c|}
\hline Gender & $\mathrm{n} / \%$ & 1. Class & 2. Class & 3. Class & 4. Class & Total \\
\hline \multirow[t]{2}{*}{ Male } & $\mathrm{n}$ & 9 & 5 & 9 & 5 & 28 \\
\hline & $\%$ & 4.7 & 2.6 & 4.7 & 2.6 & 14.5 \\
\hline \multirow[t]{2}{*}{ Female } & $\mathrm{n}$ & 42 & 51 & 44 & 28 & 165 \\
\hline & $\%$ & 21.8 & 26.4 & 22.8 & 14.5 & 85.5 \\
\hline \multirow[t]{2}{*}{ Total } & $\mathrm{n}$ & 51 & 56 & 53 & 33 & 193 \\
\hline & $\%$ & 26.4 & 29.0 & 27.5 & 17.1 & 100 \\
\hline
\end{tabular}

in their $4^{\text {th }}$. The sample consisted of $193(100 \%)$ prospective teachers, of whom $165(85.5 \%)$ were female and 28 (14.5\%) were male.

\section{Data Collection}

This section contains explanations about "Science Education Self-Efficacy Belief Scale" and "Kolb Learning Style Inventory."

\section{The Scale of Self-Efficacy Beliefs in Science Education}

The 'Science Education Self-Efficacy Belief Scale' developed by Enochs and Riggs (1990) and adapted into Turkish by Özkan et al. (2002) was used to determine the levels of preschool teachers' self-efficacy beliefs in science education. The scale consists of 23 items rated on a 5-point Likert type and two sub-dimensions: "Personal Self-Efficacy Beliefs in Science Education" and "Result Expectation in Science Education." The subscale of Personal Self-Efficacy Beliefs in Science Education in the scale consists of 13 items $(2,3,4,6,7,12$, and 16-22). The result Expectation in Science education sub-dimension consists of ten items $(1,5,8,9,10,11,13,14,15$, and 23$)$. In the reliability study conducted by Riggs and Enochs, the Cronbach Alpha value of the personal self-efficacy belief sub-dimension was found to be 0.76 . As a result of the reliability-validity study conducted for the scale adapted to Turkish by Özkan et al. (2002), the Cronbach Alpha reliability value of the personal self-efficacy beliefs in science education sub-dimension was calculated as 0.78 and the Cronbach's Alpha reliability value of the result expectation sub-dimension in science education was calculated as 0.85 . Reliability coefficient calculated as 0.70 and above is generally considered sufficient (Büyüköztürk, 2016). Based on the data, it was concluded that the scale could be used.

A descriptive interpretation of the prospective teachers' scores from the scale of self-efficacy beliefs in science education, the formula "width of the array/the number of groups to be made" (Tekin, 1993. p. 42) was calculated. In the evaluation of research findings, the reference range is interpreted as for the self-efficacy scale: 23-41 was "very low," 42-59 "low," 60-78 "medium," 79-96 "high," and 97-115 "very high;" total score ranges for personal self-efficacy perception, which consists of sub-dimensions of self-efficacy beliefs: 13-23 was "very low," 24-33 "low," 34-44 "medium," 45-54 "high," and 55-65 "very high" and total score ranges for the result expectation sub-dimension: 10-18; "very low," 19-26 "low," 27-34 "medium," 35-42 "high," and 43-50 "very high."

\section{Kolb Learning Style Inventory}

Kolb Learning Style Inventory-III (LSI-III) developed by Kolb (1999) for students and adapted to Turkish by Evin Gencel (2007) was used to determine the learning styles of prospective pre-school teachers. The validity and reliability study of the inventory was done by Evin Gencel (2007). In Evin Gencel's study, it was determined that Cronbach Alpha reliability coefficients of learning style dimensions ranged from 0.71 to $0.80(\mathrm{n}=320)$. Cronbach Alpha internal consistency coefficients calculated on the data collected in this study were 0.75 and 0.84 (concrete experience 0.79 ; reflective observation 0.75 ; abstract conceptualization 0.82 ; active experimentation 0.78 ; abstract conceptualization-concrete experience 0.84 ; and active experience-reflective observation 0.81) $(\mathrm{n}=193)$. The reliability coefficient of 0.70 or higher is generally considered acceptable for the reliability of the test scores (Büyüköztürk, 2016). Thus, it was concluded that the inventory could be used for this study.

In the Kolb Learning Style Inventory-3, four learning styles specified in the Kolb learning style model are defined. The inventory consists of twelve items with four options asking individuals to rank four learning styles that best describe their learning styles. Each option is aimed at determining concrete experience, reflective observation, abstract conceptualization, and active experience learning styles. Respondents are asked to answer the inventory answer the complementary items by giving $1,2,3$, or 4 points from the least appropriate item to the most appropriate item. The scores given to each option are added up sequentially and as a result, a score between 12 and 48 is obtained for each individual.

Combined scores are obtained as follows:

- Abstract conceptualization ( $3^{\text {rd }}$ option) - concrete experience ( $1^{\text {st }}$ option)

- Active experimentation ( $4^{\text {th }}$ option) reflective observation ( $2^{\text {nd }}$ option).

According to the information given, the combined score is obtained by subtracting the score given by the respondents to the concrete experience $(\mathrm{CE})\left(1^{\text {st }}\right.$ option $)$ score from the score given to the abstract conceptualization (AC) ( $3^{\text {rd }}$ option) while subtracting the score given to the Reflective Observation (RO) ( $2^{\text {nd }}$ option) from the score given to the Active Experimentation (AE) ( $4^{\text {th }}$ option). Combined scores range from +36 to -36 . In Figure 1, the intersection of the two combined scores in the chart arranged according to Kolb's experiential learning theory indicates the appropriate learning styles of the individuals.

As an example, to determine the learning style of the prospective teacher, in line with the points they got from the inventory:

- Concrete experience: 24 point

- Abstract conceptualization: 31 point

- Reflective observation: 23 point

- Active experimentation: 19 point

When we place the scores obtained by the prospective teacher on the chart arranged according to Kolb's experiential learning 


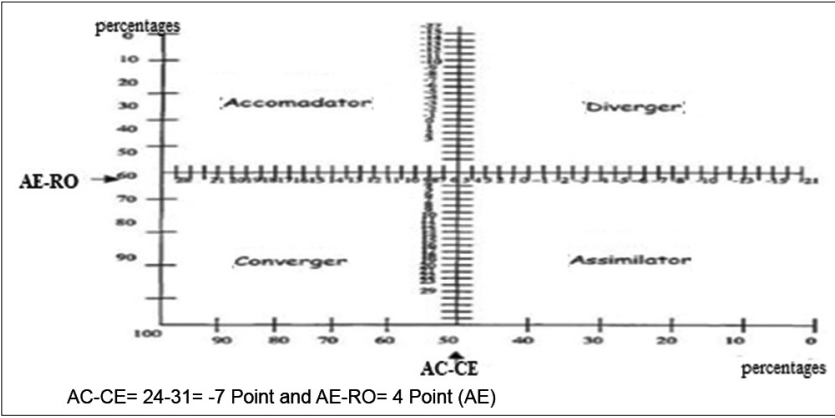

Figure 1: Chart showing learning styles determined by Kolb according to experiential learning theory

theory, it is seen that the prospective teacher has a divergent learning style.

\section{Data Collection Process}

Necessary permissions were obtained from the educational institution before the data were collected. The data were collected in the fall semester between October 16 and 30, 2019. In the data collection process, it was stated that the data would be used in a scientific study on a voluntary basis. The forms which the prospective teachers filled out completely were organized to be included in the study group. There was no time limit for prospective teachers to fill in the scales and no intervention that could affect the evaluation processes. It took an average of 30 min to complete the scales.

\section{Data Analysis}

The data obtained from the scales were examined one by one, the scores of each participant were determined, and were recorded. The data were processed using SPSS version 24.0. Pearson Product Moment Correlation (r), one-way analysis of variance (f), and Mann-Whitney $U$ test for independent samples were analyzed according to all the descriptive statistical measures required in the analyzes and the type of data groups according to the type of data groups. A 0.05 significance level was set. The normality of the data distribution was examined and the necessary test techniques were determined.

As a result of the analyzes to examine the normality of the data distribution, kurtosis value was calculated $(-1.17)$ and skewness value was 0.15 for the class levels, kurtosis value was 0.78 and skewness value was -0.42 for the self-efficacy belief scale, kurtosis value was -0.81 , and skewness value was -0.58 for learning styles. However, kurtosis value for gender variable was calculated as 2.15 and skewness value was -2.03 . Tabachnick and Fidell (2013) stated that the kurtosis and skewness values should be in the range of $+1.5--1.5$ for the data to have a normal distribution. It was determined that the data except for the gender variable had a normal distribution and satisfied the condition of homogeneity of variances.

The Mann-Whitney U-test, one of the non-parametric test methods, was used to test whether prospective pre-school teachers' learning styles and levels of self-efficacy beliefs in science education differentiate according to the gender variable. One-way analysis of variance was applied to determine whether the learning styles of prospective pre-school teachers differentiated according to the levels of self-efficacy beliefs in science education. In addition, one-sample Chi-square test was used to understand whether prospective teachers' learning style preferences differentiate according to gender variable.

- The Mann-Whitney U-test for independent samples is used to test whether the scores obtained from two unrelated samples differ significantly from each other

- One-way analysis of variance is used to test whether the difference between unrelated or more sample means is statistically different from zero

- It examines the significance of the difference between the numbers observed in each category of the variable from the expected numbers for the categories with the Chi-square test for a single sample.

\section{FINDINGS}

This section includes the data gathered from the research conducted to evaluate the relationship between prospective pre-school teachers' self-efficacy beliefs in science education and learning styles and the findings from the analyzes of these data.

\section{General Distribution of Prospective Teachers' Self-Efficacy Beliefs in Science Education}

This section involves general scores of the sub-dimensions and the levels of prospective pre-school teachers' self-efficacy beliefs in science education. Table 2 shows the total scores that prospective pre-school teachers received from the scale and its sub-dimensions of the self-efficacy beliefs in science education.

As seen in Table 2, the highest score obtained by prospective pre-school teachers regarding their levels of competences in the scale was calculated as 109.0 while the lowest score was 49.0, the scale average was 84.05 and the standard deviation was 0.44 . For personal self-efficacy perception, the highest score was 64.0 , while the lowest score was 18.0, the scale average was 47.89 , and the standard deviation was 7.48 . For the result expectation, the highest score was 50.0, the lowest score was 18.0 , the mean of the scale was 36.17 , and the standard deviation was 5.14. In line with the findings obtained from the scale of the prospective pre-school teacher's self-efficacy beliefs in science education, it was found that prospective teachers' self-efficacy beliefs in science education were very high, while their personal self-efficacy beliefs and result expectation sub-dimensions were at a high level.

\section{Descriptive Statistics on Prospective Teachers' Learning Styles}

The distribution of prospective pre-school teachers learning styles is given in Table 3 .

When Table 3 is examined, it is seen that $30(15.5 \%)$ of the prospective teachers had an accommodator learning style, $28(14.5 \%)$ convergent, $73(37.8 \%)$ has divergent, and $62(32.2 \%)$ assimilator. As a result of the one-variable 
Chi-square test performed to understand whether this difference between prospective teachers' learning styles was meaningful or not, it was found that the difference between prospective teachers' learning styles was statistically significant $\left[x^{2}(3)=32.02, \rho<0.05\right]$. In line with the findings obtained, it was found that prospective pre-school teachers have divergent (37.8\%) and assimilator (32.2\%) learning styles at most while they have accommodator (15.5\%) and convergent (14.5\%) learning styles at least.

\section{Prospective Teachers' Self-Efficacy Beliefs in Science Education According to their Learning Styles}

Descriptive analysis of prospective pre-school teachers' learning styles according to their self-efficacy beliefs in science education is given in Table 4.

When Table 4 is examined, it is seen that prospective teachers who have the highest self-efficacy belief levels and personal self-efficacy perceptions toward science education have an assimilator learning style $(\overline{\mathrm{x}}=85.61, \overline{\mathrm{x}}=46.83)$, while prospective teachers with the highest self-efficacy perception level they have divergent learning styles $(\overline{\mathrm{x}}=35.2)$. In addition, prospective teachers with the lowest levels of self-efficacy beliefs in science education have a convergent learning style $(\overline{\mathrm{x}}=80.53)$, prospective teachers with the lowest personal self-efficacy perceptions have convergent learning styles.

\begin{tabular}{|c|c|c|c|c|c|}
\hline Self-efficacy & $\mathbf{n}$ & Minimum & Maximum & $x$ & $\mathbf{S}$ \\
\hline General self-efficacy & 193 & 49.0 & 109.0 & 84.05 & 0.44 \\
\hline Personal self-efficacy & 193 & 18.0 & 64.0 & 47.89 & 7.48 \\
\hline Result expectation & 193 & 18.0 & 50.0 & 36.17 & 5.14 \\
\hline
\end{tabular}

\begin{tabular}{|c|c|c|c|c|c|}
\hline Learning styles & $\mathbf{F}$ & $\%$ & $\chi^{2}$ & SD & $\mathrm{p}$ \\
\hline Accommodator & 30 & 15.5 & 32.016 & 3 & 0.00 \\
\hline Convergent & 28 & 14.5 & & & \\
\hline Divergent & 73 & 37.8 & & & \\
\hline Assimilator & 62 & 32.2 & & & \\
\hline Total & 193 & 100.0 & & & \\
\hline
\end{tabular}

$(\overline{\mathrm{x}}=45.00)$, while prospective teachers with the lowest result expectation and self-efficacy perceptions have accommodator learning style $(\overline{\mathrm{x}}=35.23)$.

One-dimensional analysis of variance was conducted to determine whether prospective pre-school teachers' learning styles differ according to their levels of self-efficacy beliefs in science education. Analysis results regarding the sub-dimensions and the levels of the self-efficacy beliefs in science education according to the learning styles of the prospective teachers are given in Table 5.

As shown in Table 5, there was no significant difference between prospective pre-school teachers' self-efficacy beliefs in science education according to their learning styles $[F(3,189)=2.22, \rho>0.05]$. There was no significant difference between prospective pre-school teachers' learning styles in terms of result expectation beliefs $[\mathrm{F}(3,189)=2.48, \rho>0.05]$. There was no significant difference between prospective pre-school teachers' learning styles and personal self-efficacy beliefs $[F(3,198)=0.75, \rho>0.05]$.

\section{Prospective Teachers' Self-Efficacy Beliefs in Science Education According to Their Gender}

Mann-Whitney test for independent sample was conducted to understand whether levels of prospective pre-school teachers' self-efficacy beliefs in science education differentiate according to their gender. The findings of the Mann-Whitney U-test are given in Table 6.

As shown in Table 6 there was no statistically significant difference between the levels of prospective pre-school teachers' self-efficacy beliefs in science education according to their gender $[U=2,303.50, \rho>-0.05]$. In addition, there is no statistically significant difference between personal self-efficacy and result expectation of the scale of the self-efficacy beliefs in science education according to the gender of prospective teachers $[\mathrm{U}=2,231.50, \rho>.05$; $\mathrm{U}=2,156.00, \rho>0.05]$.

Prospective Teachers' Self-Efficacy Beliefs in Science Education According to their Class Levels

The analysis of the scores obtained by prospective pre-school teachers from the scale of the self-efficacy beliefs in science education and its sub-dimensions according to their class levels is given in Table 7.

Table 4: The descriptive statistical values of the prospective teachers' scores obtained from the self-efficacy belief scale in science education regarding the learning styles

\begin{tabular}{|c|c|c|c|c|c|c|c|c|c|}
\hline \multirow[t]{2}{*}{ Learning styles } & \multicolumn{3}{|c|}{ Self-efficacy } & \multicolumn{3}{|c|}{ Personal self-efficacy } & \multicolumn{3}{|c|}{ Results expectancy } \\
\hline & $\mathbf{n}$ & $x$ & S & $\mathbf{n}$ & $x$ & $S$ & $\mathbf{n}$ & $x$ & $S$ \\
\hline Accommodator & 30 & 82.07 & 10.19 & 30 & 46.83 & 1.46 & 30 & 35.23 & 0.81 \\
\hline Convergent & 28 & 80.53 & 10.89 & 28 & 45.00 & 1.41 & 28 & 35.54 & 1.15 \\
\hline Divergent & 73 & 84.90 & 9.41 & 73 & 48.19 & 0.905 & 73 & 36.71 & 0.55 \\
\hline Assimilator & 62 & 85.61 & 10.21 & 62 & 49.35 & 0.83 & 62 & 36.26 & 0.69 \\
\hline Total & 193 & 84.06 & 10.11 & 193 & 47.89 & 0.53 & 193 & 36.17 & 0.37 \\
\hline
\end{tabular}




\begin{tabular}{|c|c|c|c|c|c|c|}
\hline Variables & Source & Sum of square & Df & Mean square & $\mathbf{F}$ & Sig \\
\hline \multirow[t]{3}{*}{ General self-efficacy } & Between groups & 668.50 & 3 & 222.835 & 2.222 & 0.087 \\
\hline & Within the group & 18951.869 & 189 & 100.274 & & \\
\hline & Total & 19620.373 & 192 & & & \\
\hline \multirow[t]{3}{*}{ Result expectation } & Between groups & 407.04 & 3 & 135.68 & 2.48 & 0.062 \\
\hline & Within the group & 10329.67 & 189 & 54.65 & & \\
\hline & Total & 10736.71 & 192 & & & \\
\hline \multirow{3}{*}{$\begin{array}{l}\text { Personal } \\
\text { self-efficacy }\end{array}$} & Between groups & 59.53 & 3 & 19.84 & 0.75 & 0.525 \\
\hline & Within the group & 5021.16 & 189 & 26.57 & & \\
\hline & Total & 5080.69 & 192 & & & \\
\hline
\end{tabular}

\begin{tabular}{llccccc}
\hline $\begin{array}{l}\text { Table 6: U-test results of prospective teachers' } \\
\text { self-efficacy beliefs in science education according to } \\
\text { their gender }\end{array}$ & Gender & $\mathbf{n}$ & $\begin{array}{c}\text { Mean } \\
\text { rank }\end{array}$ & $\begin{array}{c}\text { Sum of } \\
\text { rank }\end{array}$ & U & p \\
\hline Self-efficacy & & & 97.23 & 2227.50 & 2303.50 & 0.98 \\
& Male & 28 & 96.97 & 15998.50 & & \\
\hline General self-efficacy & Female & 165 & 96.97 & & \\
Personal & Male & 28 & 94.20 & 2637.50 & 2231.50 & 0.57 \\
self-efficacy & Female & 165 & 97.48 & 16083.50 & & \\
Result expectation & Male & 28 & 102.50 & 2870.00 & 2156.00 & 0.78 \\
& Female & 165 & 96.07 & 15851.00 & & \\
\hline
\end{tabular}

\begin{tabular}{|c|c|c|c|c|c|c|c|c|c|}
\hline \multirow[t]{2}{*}{ Class level } & \multicolumn{3}{|c|}{ Self-efficacy } & \multicolumn{3}{|c|}{$\begin{array}{c}\text { Personal } \\
\text { self-efficacy }\end{array}$} & \multicolumn{3}{|c|}{$\begin{array}{c}\text { Result } \\
\text { expectation }\end{array}$} \\
\hline & n & $x$ & $S$ & n & $x$ & $S$ & n & $x$ & $S$ \\
\hline 1. Class & 51 & 84.29 & 11.39 & 51 & 47.43 & 8.67 & 51 & 36.86 & 6.06 \\
\hline 2. Class & 56 & 82.57 & 9.26 & 56 & 46.89 & 6.39 & 56 & 35.67 & 5.16 \\
\hline 3. Class & 53 & 84.83 & 9.75 & 53 & 48.83 & 7.56 & 53 & 36.00 & 4.13 \\
\hline 4. Class & 33 & 84.96 & 10.11 & 33 & 48.78 & 7.08 & 33 & 36.18 & 5.13 \\
\hline Total & 193 & 84.05 & 10.10 & 193 & 47.89 & 7.47 & 193 & 36.16 & 5.14 \\
\hline
\end{tabular}

As shown in Table 7, the highest average of the total scores of prospective pre-school teachers in the scale of self-efficacy beliefs in science education belonged to the $4^{\text {th }}$ class prospective teachers $(=84.96)$, and the lowest average of the total scores belongs to the $2^{\text {nd }}$ year prospective teachers $(=82.57)$. The highest average of the total scores of personal self-efficacy beliefs belonged to $3^{\text {rd }}$ class prospective teachers $(=48.83)$, while the average of the lowest total scores belonged to $2^{\text {nd }}$ year teachers $(=46.89)$. It was observed that the average of the total score of the result expectation belonged to $1^{\text {st }}$ year prospective teachers $(=36.86)$, and the average of the lowest total scores belonged to $3^{\text {rd }}$ year prospective teachers $(=36.00)$.

One-dimensional analysis of variance was conducted to determine whether there was a statistically significant difference between the levels of prospective pre-school teachers' self-efficacy beliefs in science education according to their class levels. The findings of the one-dimensional analysis of variance are given in Table 8.

As shown in Table 8, a significant difference was not found between the levels of prospective pre-school teachers' self-efficacy beliefs in science education according to their class levels $[F(3,189)=-0.60, p>0.05]$. There was no significant difference between prospective pre-school teachers' personal self-efficacy beliefs according to their class levels $[\mathrm{F}(3,189)=0.83, \mathrm{p}>0.05]$. There was no significant difference between prospective pre-school teachers' result expectation self-efficacy beliefs according to their grade levels $[\mathrm{F}(3,189)=0.49, \mathrm{p}>0.05]$.

\section{Learning Styles of Prospective Teachers According to their Gender}

The Chi-square results regarding whether the learning styles of prospective pre-school teachers differentiate according to their gender are given in Table 9.

As shown in Table 9, 50\% of male prospective teachers had an assimilator learning style, 39.3\% divergent, 7.1\% accommodator, and $3.6 \%$ convergent. It was seen that the female prospective teachers had $37.6 \%$ divergent, $29.1 \%$ assimilator, $17 \%$ accommodator, and $16.4 \%$ convergent learning style. As a result of the Chi-square test, it was seen that there was no significant difference between the learning styles of prospective teachers according to their gender $\left[\chi^{2}(3)=7.46, p>0.05\right]$.

\section{RESULTS AND DISCUSSION}

Preschool teachers have a great responsibility to ensure that their science lessons are of high quality and at the desired levels (Savran, 2002). For a quality science education, it is possible for preschool teachers to use affective characteristics in their profession and to use their knowledge, skills, and abilities effectively in education and teaching life. Self-efficacy beliefs in science education come first among these affective characteristics. Preschool teachers can raise students' selfefficacy beliefs in science education only by raising own their self-efficacy beliefs. The foundations of these beliefs should be laid and developed in the faculties where preschool teachers 
Özdemir and Hastürk: Self- Efficacy Beliefs in science education and learning styles

\begin{tabular}{|c|c|c|c|c|c|c|}
\hline Variables & Source & Sum of square & Df & Mean square & $\mathbf{F}$ & Sig. \\
\hline \multirow[t]{3}{*}{ Self-efficacy } & Between groups & 185.62 & 3 & 61.87 & 0.60 & 0.61 \\
\hline & Within the group & 19434.7 & 189 & 102.8 & & \\
\hline & Total & 19620.3 & 192 & & & \\
\hline \multirow[t]{3}{*}{ Personal Self-efficacy } & Between groups & 139.861 & 3 & 46.62 & 0.83 & 0.47 \\
\hline & Within the group & 10596.8 & 189 & 56.06 & & \\
\hline & Total & 10736.7 & 192 & & & \\
\hline \multirow[t]{3}{*}{ Result expectation } & Between groups & 39.53 & 3 & 13.17 & 0.49 & 0.68 \\
\hline & Within the group & 5041.16 & 189 & 26.67 & & \\
\hline & Total & 5080.69 & 192 & & & \\
\hline
\end{tabular}

\begin{tabular}{|c|c|c|c|c|c|c|c|c|c|}
\hline \multirow[t]{2}{*}{ Gender } & \multirow[t]{2}{*}{$n / \%$} & \multicolumn{4}{|c|}{ Language styles } & \multirow[t]{2}{*}{ Total } & \multirow[t]{2}{*}{$\chi^{2}$} & \multirow[t]{2}{*}{ SD } & \multirow[t]{2}{*}{ p } \\
\hline & & Accommodator & Convergent & Divergent & Assimilator & & & & \\
\hline \multirow[t]{2}{*}{ Male } & $\mathrm{n}$ & 2 & 1 & 11 & 14 & 28 & 7.46 & 3 & 0.59 \\
\hline & $\%$ & 7.1 & 3.6 & 39.3 & 50.0 & 100.0 & & & \\
\hline \multirow[t]{2}{*}{ Female } & $\mathrm{n}$ & 28 & 27 & 62 & 48 & 165 & & & \\
\hline & $\%$ & 17.0 & 16.4 & 37.6 & 29.1 & 100.0 & & & \\
\hline \multirow{2}{*}{ Total } & $\mathrm{n}$ & 30 & 28 & 73 & 62 & 193 & & & \\
\hline & $\%$ & 15.5 & 14.5 & 37.8 & 32.1 & 100.0 & & & \\
\hline
\end{tabular}

are educated before starting their profession. To be high quality and authenticity of the education they receive from their teacher education faculty their individual learning styles should not be ignored. In this paper; the findings obtained are discussed under main headings.

It was determined that these prospective pre-school teachers had high self-efficacy perceptions in the scores they got from the scale of self-efficacy beliefs in science education and its sub-dimensions. According to this result, it can be thought that the field and vocational education that the prospective teachers received improved their own abilities and judgments positively towards the ability to provide an effective science education and consequently their self-efficacy perception increased (Azar, 2010; Yenilmez and Kakmac1, 2008; Y1lmaz and Gürçay, 2011). When the literature on self-efficacy was examined, it was found that prospective pre-school teachers have high self-efficacy perceptions toward science education (Akbaş and Çelikkaleli, 2006; Altunçekiç et al., 2005; Olgan et al., 2014; Yaman et al., 2004). For this reason, the results of this study have parallels with other studies. Czerniak and Haney (1998) thought that teachers with high self-efficacy perception levels toward science education could best meet their students' needs. They state that pre-school teachers with high levels of self-efficacy tend to use student-centered teaching techniques, have an understanding of inquiry-based education and practice confident activities in science education (as cited in Olgan et al., 2014).

With this study, there was no significant difference between the levels of self-efficacy beliefs in science education, the sub-dimensions of personal self-efficacy perception and result expectancy levels, and the gender of prospective teachers. When the literature was examined, it showed that the levels of prospective pre-school teachers' self-efficacy beliefs and sub-dimensions did not differentiate according to gender. Similar to this result, Şenol (2012) emphasized in her/his study with prospective pre-school teachers that self-efficacy perception levels do not differentiate according to gender. Similarly, Kahyaoğlu and Yangın (2007) found that self-efficacy levels did not differentiate according to gender in their study with prospective teachers in the primary education department. Akbaş and Çelikkaleli (2006) and Berkant and Ekici (2007) reached a similar result in their studies with prospective teachers. Unlike the results of this study, Üredi and Üredi (2006) found that women's self-efficacy perceptions were high, while Çalışkan et al. (2010) found that men had higher self-efficacy perceptions. However, the common result is that gender does not differ according to the level of self-efficacy perception. The reason is that it can be shown that there is less gender discrimination today, and equality between women and men has gained in importance around the world.

Another finding from this study was that there was no statistically significant relationship between prospective pre-school teachers' general self-efficacy beliefs in science education, personal self-efficacy sub-dimension and result expectancy sub-dimension, and learning styles. The reason for this situation can be shown that the self-efficacy belief levels of all prospective teachers were very high. Denizoğlu (2008) determined that individuals with an assimilating learning style have lower self-efficacy beliefs than individuals with a distinctive learning style. She stated that prospective teachers' general self-efficacy beliefs in science education 
differ according to their personal self-efficacy belief levels. She also stated that there was a significant difference between personal self-efficacy belief sub-dimension and individuals with distinctive, transformative and assimilating learning style.

It has been determined that most of these prospective pre-school teachers had a diverger learning style at most, then assimilator, accommodator, and finally converger. In line with these findings, it can be said that prospective pre-school teachers are generally individuals who like problem solving, can see the whole from the part, give importance to the details, adopt learning by doing and living, follow the graded teaching, interpret and reach the truth by adopting all ideas. When other studies in the literature were examined, it was seen that other prospective teachers also mostly had diverger and assimilator learning styles, and there were less prospective teachers with accommodator and converger learning styles. In this way, the findings in the study are in parallel with the studies conducted in the previous years (Hasırc1, 2006; Koç, 2007; Zengin and Alşahan, 2012; Zorlu et al., 2019). It is possible to encounter different results with the findings of this study and the studies conducted in the previous years. Kurtuluş (2019) found in their study that prospective teachers had assimilator learning style mostly. The reason for this difference can be thought to be due to the differences between the education level of the sample group and learning environments because learning styles change people's experiences and lives (Kolb, 1984).

In line with these findings, there is no significant relationship between prospective pre-school teachers' gender and learning styles. In the previous studies, the relationship between prospective teachers' learning styles and their gender was examined and there was no significant difference (Çağlayan and Taşğın, 2009; Koç, 2007; Şimşek, 2007). In the literature, it is possible to encounter results that do not correspond to the findings in the study. In the previous studies, it was determined that prospective teachers have assimilator learning style at most (Deryakulu et al., 2010; Karademir and Tezel, 2010; Kılıç, 2002; Peker, 2005).

\section{RECOMMENDATIONS}

- The study was conducted with the data from one university. This study can be expanded with prospective preschool teachers from different universities

- The study was done using only quantitative data. For more detailed study, the results can be detailed using both qualitative and quantitative data

- More detailed results about prospective teachers can be obtained by adding different variables to the scales used in the study

- Since the genders of prospective teachers do not show a normal distribution, studies can be conducted about male prospective teachers' preschool preferences

- Considering that the majority of prospective teachers have diverger and assimilator learning styles, education programs can be updated by program developers
- Preschool experts and educators, using graded teaching in science education; they can design science activities by considering individuals who aim to interpret and reach the whole from part.

\section{ACKNOWLEDGMENTS}

This study formed part of the first author's master's thesis conducted under the supervision of the second author.

\section{REFERENCES}

Akbaş A., \& Çelikkaleli, Ö. (2006). An investigation of primary school teacher candidates' self-efficacy beliefs in science teaching by gender, type of education and universities. Mersin University Journal of the Faculty of Education, 2(1), 98-110.

Aktaş Arnas, Y., Bilaloğlu, R.G., \& Aslan, D. (2007). Science Education in Pre-school Period. London: Kök Press.

Altunçekiç, A., Yaman, S., \& Koray, Ö. (2005). The research on prospective teachers' selfefficacy belief level and problem solving skills. Каstamonu Education Journal, 13(1), 93-102.

Ayvac1, H.Ş., \& Özbek, D. (2017). Education of the Nature of Science in Preschool Period, Pre-school Science Education from Theory to Practice. Turkey: Pegem Academy.

Azar, A. (2010). In-service and pre-service secondary science teachers' selfefficacy beliefs about science teaching. ZKU Journal of Social Sciences, $6(12), 235-252$.

Bandura, A. (1977). Self-efficacy: Toward a unifying theory of behaviour change. Psychological Review, 84, 191-215.

Berkant, G.H., \& Ekici, G. (2007). Evaluation of the relationship between teacher self-efficacy belief levels and intelligence types in science teaching of prospective classroom teachers. Journal of the Cukurova University Institute of Social Sciences, 16(1), 113-132.

Brown, E.T. (2005). The influence of teachers' efficacy and beliefs regarding mathematics instruction in the early child classroom. Journal of Early Childhood Teacher Education, 26, 239-257.

Büyüköztürk, Ş. (2016). Data Analysis Handbook for Social Sciencesstatistics, Research Design, SPSS Applications and Interpretation. Turkey: Pegem Academy.

Çağlayan, H.S., \& Taşğın, Ö. (2009). Examination of the learning styles of candidate students applying for the physical education and sports school exam. Selçuk University Journal of Social Science Institute, 20, 199-212.

Çalışkan, S., Sezgin Selçuk, G., \& Özcan, Ö. (2010). Self-efficacy beliefs of physics student teachers': Effects of gender, class level and academic achievement. Kastamonu Education Journal, 18(2), 449-466.

Çamlıbel Çakmak, Ö. (2006). Investigation of the relationship Between Preschool Pre-service Teachers Attitudes Towards Science and a Science Teaching and their Understanding Levels of Some Science Concepts. Bolu: Unpublished Master Thesis, Abant İzzet Baysal University, Institute of Social Science.

Can, M., \& Şahin Çakır, Ç. (2015). Investigating prospective kindergarten teachers science and science teaching attitudes. Abant İzet Baysal University Journal of Faculty of Education, 15(2), 13-26.

Çilenti, K. (1985). Science Education Technology. Ankara: Kadığlu Press.

Czerniak, C.M., \& Haney, J.J. (1998). The effect of collaborative concept mapping on elementary preservice teachers' anxiety, efficacy, and achievement in physical science. Journal of Science Teacher Education, 9(4), 303-320.

Denizoğlu, P. (2008). The Assessment of the Relation Between Self-efficacy Belief Levels, Learning Styles of Science Teacher Candidates Towards Science Teaching and their Attitudes Towards Science Teaching. Adana: Unpublished Master Thesis, Çukurova University, Institute of Social Science.

Deryakulu, D., Büyüköztürk, Ş., \& Özçınar, H. (2010). Predictors of academic achievement of student $1 \mathrm{ct}$ teachers with different learning styles. International Journal of Human and Social Sciences, 3(10), 5-9.

Duschl, R.A., Schweingruber, H.A., \& Shouse, A.W. (2007). Taking Science 
to School: Learning and Teaching Science in Grades K-8. United States: National Academies Press.

Eğin Ișık, T., (2019). An Investigation of the Relationship Between Learning Styles and Social Competence and Social Skills of Preschool Students. Konya: Unpublished Master Thesis, Necmettin Erbakan University, Institute of Educational Sciences.

Enochs, L.G., \& Riggs, I.M. (1990). Further development of an elementary science teaching efficacy belief instrument: A preservice elementary scale. School Science and Mathematics, 90(8), 694-706.

Erbaş, S., Ergül, R., Şimşekli, Y., \& Özdilek, Z. (2002). Pre-school Science Education. London: Ekin Press.

Eschach, H. (2011). Science for young children: A new frontier for science education. Journal of Science Education and Technology, 20(5), 435-443.

Eshach, H., \& Fried, M.N. (2005). Should science be taught in early childhood? Journal of Science Education and Technology, 14, 315-336.

Evin Gencel, İ. (2007). the study of adapting the learning styles inventory-III based on Kolb's experiential learning theory into Turkish. Dokuz Eylul University The Journal of Graduate School of Social Sciences, 9(2), 120-139.

Fraenkel, J.R., \& Wallen, N.E. (2006). How to Design and Evaluate Research in Education. 6 $^{\text {th }}$ ed. United States: McGraw-Hill Education.

Gözüm, A. (2015). Determining the Socio-scientific Attitudes and Cognitive Structures of the Preschool, Primary and Science Teachers in Terms of Self-efficacies in Science Education: Kars Province Sample. Samsun: Unpublished Master Thesis, Ondokuz Mayis University, Institute of Educational Sciences.

Grieshaber, S., \& Diezmann, C. (2000). The challenge of teaching and learning science with young children. In: Promoting Meaningful Learning: Innovations in Educating Early Childhood Professionals. United States: SAGE. pp. 87-94.

Gülay, H. (2010). Peer Relationships in the Preschool Period. London: Pegem Press.

Hamurcu, H. (2003). Science teaching "Project Approach" in preschool education. Journal of Educational Research, 13, 66-72.

Hanley, G.P., Cammilleri, A.P., Tiger, J.H., \& Ingvarsson, E.T. (2007). Towards a method for describing preschoolers' activity preferences. Journal of Applied Behavior Analysis, 40, 603-618.

Hanley, G.P., Tiger, J.H., Ingvarsson, E.T., \& Cammilleri, A.P. (2009). Influencing preschoolers' free-play activity preferences: An evaluation of satiation and embedded reinforcement. Journal of Applied Behavior Analysis, 42, 33-41.

Hasırc1, Ö. (2006). Learning styles of prospective primary school teachers: Cukurova university case. Journal of Theory and Practice in Education, 2(1), 15-25.

Jones, M.G., \& Carter, G. (2007). Science teacher attitudes and beliefs. In: Abell, S.K., \& Lederman, N.G., (Eds.), Handbook of Research on Science Education. Mahwah: Erlbaum. pp. 1067-1104

Kahyaoğlu, M., \& Yangın, S. (2007). Views of prospective teachers in elementary school teaching departments about professional self-efficacy. Kastamonu Education Journal, 15(1), 73-84

Karademir, E., \& Tezel, Ö. (2010). Investigation of primary teacher candidates' learning styles by demographic variables. Pamukkale University Journal of Education, 28, 129-145.

Karasar, N., (2006). Scientific Research Method. Oslo, Norway: Nobel Press.

Kesicioğlu, O.S. (2019). Mathematics education and its importance in early childhood period. In Uludağ, G., (Ed.), Mathematics Education in Early Childhood Period. London, United Kingdom: Atlas Press. pp. 17-25.

Kıldan, O., \& Pektaş, M. (2009). Preschool teachers' views regarding the teaching of the subjects related to science and nature during early childhood. Ahi Evran University Journal of Kırşehir Educational Faculty, 10(1), 113-127.

Kılıç, E. (2002). The effect of dominant learning style on the choice of learning activities and academic achievement. Educational Sciences and Practice, 1(1), 1-15.

Koç, D. (2007). Middle School Students Learning Styles: The Relationship Between Student Science Achievement and Attitudes (Lone of Afyonkarahisar). Afyonkarahisar: Unpublished Master Thesis, Afyon Kocatepe University, Institute of Social Sciences.

Kolb, D.I. (1984). Experiential Learning-experience as the Source of
Learning and Development. United States: Prentice Hall.

Kolb, D.A. (1999). Learning Style Inventory: Version 3. Boston: Hay/McBer Training Resources Group.

Kurtuluş, E. (2019). Investigation of Teacher Candidates' Learning Styles and Intention to Use Technology. İstanbul: Unpublished Master Thesis, Yıldız Teknik University, Institute of Social Science.

La Paro, K.M., Pianta R.C., \& Stuhlman, M. (2004). The classroom assessment scoring system: Findings from the prekindergarten year. The Elementary School Journal, 104, 409-426.

Levitt, K.E. (2002). An analysis of elementary teachers' beliefs regarding the teaching and learning of science. Science Education, 86, 1-22.

McDevitt, T.M., Heikkinen, H.W., Alcorn, J.K., Ambrosio, A.L., \& Gardner, A.L. (1993). Evaluation of the preparation of teachers in science and mathematics: Assessment of preservice teachers' attitudes and beliefs. Science Teacher Education, 77, 593-610.

Nacar, S., \& Kutluca, A. (2020). Exploration of the pedagogical content knowledge of a preschool teacher on science teaching. Mersin University Journal of the Faculty of Education, 16(3), 529-545.

Nayfeld, I., Brenneman, K., \& Gelman, R. (2011). Science in the classroom: Finding a balance between autonomous exploration and teacher-led instruction in preschool settings. Early Education and Development, 22, 970-988.

Nespor, J. (1987). The role of beliefs in the practice of teaching. Journal of Curriculum Studies, 19(4), 317-328.

Olgan, R., Güner Alpaslan, Z., \& Öztekin, C. (2014). Factors influencing pre-service early childhood teachers' outcome expectancy beliefs regarding science teaching. Journal of Educational and Science, $39(173), 288-300$

Özkan, Ö., Tekkaya, C., \& Cakıroğlu, J. (2002). Science Prospective Teachers' Level of Understanding of Science Concepts, Attitudes Towards Science Teaching and Self-efficacy Beliefs. Ankara: National Science and Mathematics Education Congress, Ankara.

Özok Bulut, N. (2020). Reflections of Early Childhood Teachers'Knowledge and Attitude Levels Towards their Science Education Practices. Eskişehir: Unpublished Master Thesis, Anadolu University, Institute of Educational Sciences.

Peker, M. (2005). The relationship between learning styles and mathematics achievement of students who have become elementary school mathematics teachers. Educational Research Journal, 21, 200-210.

Savran, A. (2002). Preservice Science Teachers'Efficacy Beliefs Regarding Science Teaching and their Classroom Management Beliefs. Ankara: Unpublished Master Thesis, Middle East Technical University, Institute of Science.

Senol, F.B. (2012). The Comparison of Teacher Self-efficacy Beliefs Between Preservice Preschool Teachers and Preschool Teachers. Afyon: Unpublished Master Thesis, Afyon Kocatepe University, Institute of Educational Sciences.

Şimşek, Ö. (2007). The Development of Marmara Learning Style Inventory and Investigating 9-11 Age Students Learning Styles. İstanbul: Unpublished $\mathrm{PhD}$ Thesis, Marmara University, Institute of Educational Sciences.

Tabachnick, B.G., \& Fidell, L.S. (2013). Using Multivariate Statistics. $6^{\text {th }}$ ed. Boston: Pearson Education.

Tekin, H. (1993). Measurement and Evaluation in Education. London: Yarg1 Press.

Ünal, M., \& Akman, B. (2006). Early childhood teachers' attitudes towards science teaching. Hacettepe University Journal of Educational Faculty, $30,251-257$

Üredi, I., \& Üredi, L. (2006). Comparison of Classroom Teacher Candidates' Self-efficacy Beliefs in Science Teaching According to their Gender, their Classes and their Level of Success. Mersin University Journal of Faculty Education, 1(2), 250-260.

Yaman, S., Cansüngü, Ö., \& Altunçekiç, A. (2004). A research on the investigation of the self-sufficiency belief levels of the science education teacher candidates. The Journal of Turkish Educational Sciences, 2(3), 355-364.

Yenilmez, K., \& Kakmac1, Ö. (2008). The level of self-efficacy beliefs at students at elementary mathematics education department. Journal of Eskişehir Osmangazi University Social Sciences, 9(2), 1-21.

Yılmaz, M., \& Gürçay, D. (2011). Determination of variables that predict 
biology and physics teacher candidates' teacher self-efficacy. Cukurova University Faculty of Education Journal, 1(40), 53-60.

Yoshikawa, H., Weiland, C., Brooks-Gunn, J., Burchinal, M., Espinosa, L., Gormley, W., \& Zaslow, M.J. (2013). Investing in Our Future: The Evidence Base on Preschool Education. United States: Society for Research in Child Development and Foundation for Child Development.
Zengin, R., \& Alşahan, Ö. (2012). The evaluation of learning styles of some candidates teachers in terms of some variables. Education Sciences, 7(1), 133-139.

Zorlu, Y., Zorlu, F., \& Dinç, S. (2019). Investigation of relationships between the preservice science teachers' life skills and metacognitive awareness. Necatibey Faculty of Education, Electronic Journal of Science and Mathematics Education, 13(1), 302-327. 